This is a post print of:

Rubiales D. \& Mikic, A., 2015.

Introduction: Legumes in sustainable agriculture.

Critical Reviews in Plant Sciences 34: 1-3.

https://doi.org/10.1080/07352689.2014.897896

The printed version might be visited at:

http://www.tandfonline.com/doi/pdf/10.1080/07352689.2014.897896 


\title{
Introduction: Legumes in sustainable agriculture
}

\author{
Diego Rubiales ${ }^{1}$ and Aleksandar Mikic ${ }^{2}$ \\ ${ }^{1}$ Institute for Sustainable Agriculture, CSIC, Apdo.4048, 14080 Córdoba, Spain \\ ${ }^{2}$ Institute of Field and Vegetable Crops, Novi Sad, Serbia
}

World population is predicted to double by 2050 (http://www.fao.org), imposing an increasing demand for food that comes together with an increasing concern on environment and food security. Under this pressing scenario for agriculture, the widely acknowledged beneficial role of legumes in cropping systems, by increasing biological nitrogen fixation, reducing energy costs, improving soil physical conditions and biodiversity, is more needed than ever (Curty et al., 2014; Peix et al., 2014). In addition to this, legumes are important food and feed crops, being key components of the Mediterranean diet, and even staple crops in other regions (Vaz Paatto et al., 2014), with an increasing role as forage producing high-quality meat and milk (Boelt et al., 2014). Legumes are also gaining importance for their health benefits (Arnoldi et al., 2014).

Despite these advantages, legume cultivation did not meet the expectations and remains below that of other crops, such as cereals. This has been accompanied by a progressive replacement of traditional farming systems with industrialized, largely cerealbased systems, heavily reliant upon fossil fuels. As a result, acreage of most temperate legumes (pea, faba bean, vetches, lupin) has declined worldwide in the last 50 years (table 1). We can be more optimistic on the trend showed by warm-season legumes 
(soybean, cowpea, common bean, groundnut, pigeonpea). These are increasing in acreage, with the remarkable boost in soybean, but still, far below major cereals. Regional tendencies are also particularly notorious, with a remarkable European general trend for decrease of most legumes, including common bean, in spite of the political efforts made by the European Union and national governments to promote legume cultivation with subsidies. Soybean is the only legume whose acreage is continuously increasing in Europe, reaching 3.45 million ha in 2012, more than all other legumes together. This contrasts with the general increasing trend of all legumes in America and Oceania in which legumes where they are traded at world prizes.

Many reasons have been given for this decline, but low and unstable yields as well as susceptibility to biotic (Rubiales et al., 2014) and abiotic stresses (Araujo et al., 2014) are chiefly to blame. In fact, average yield of temperate legumes has increased relatively little during past 50 years, with a just about $50 \%$ increase for most legumes. The highest yield increases (around 100\%) have been achieved for lentil, groundnut and soybean, which are still below the increases achieved by major cereal crops (130 to 160\%) (FAOSTAT, 2013).

Given the limited resources of fossil energy, and renewing health and environmental concerns, it is time to reassess the potential role of legumes as source of $\mathrm{N}$ for cropping systems. To stimulate wider adoption, the crop should be improved to be more attractive both to producers and to users. Breeding for improved crop cultivars, to better sustain livelihood and increase the economic return to farmers, has been undertaken for many years. Significant progress in breeding annual (Duc et al., 2014) and perennial (Annicchiarico et al., 2014; Boelt et al., 2014) legumes are being achieved. Important genetic variation for all these traits of interest exists, providing an excellent resource for plant breeders (Mykal et al., 2014). Fast and reliable screening 
methods have been adjusted to fulfil the needs of breeding programmes for quality traits for food (Vaz Patto et al., 2014) and feed uses (Phelan et al., 2014), as well as for resistances to biotic (Rubiales et al., 2014) and abiotic stresses (Araujo et al., 2014). Many of these traits of interest have already been incorporated into modern cultivars, but several others, many of which are controlled quantitatively by multiple genes, have been more difficult to handle. Breeding effectiveness will soon increase with the adoption of the new improvements in marker technology together with the integration of comparative mapping and functional genomics (Annicchiarico et al., 2014; Duc et al., 2014; Varshney et al., 2014). Enhanced seed production technologies will ensure that the benefits from the improvements brought about by modern plant breeding are made readily available to farmers (Boelt et al., 2014).

\section{References:}

Annicchiarico, P., Barrett, B., Brummer, E. C., Julier, B., Marshall, A. H., 2014. Achievements and challenges in improving temperate perennial forage legumes. Critical Reviews in Plant Sciences, this issue.

Araújo, S. S., Beebe, S., Crespi, M., Delbreil, B., González, E. M., Gruber, V., LejeuneHenaut, I., Link, W., Monteros, M. J., Prats, E., Rao, I., Vadez, V., Vaz Patto, M. C., 2014. Abiotic stress responses in legumes: Strategies used to cope with environmental challenges. Critical Reviews in Plant Sciences, this issue

Arnoldi, A., Zanoni, C., Lammi, C., Boschin, G., 2014. The role of grain legumes in the prevention of hypercholesterolemia and hypertension. Critical Reviews in Plant Sciences, this issue. 
Boelt, B., Julier, B., Karagić, D., and Hampton, J., 2014. Legume seed production meeting market requirements and economic impacts. Critical Reviews in Plant Sciences, this issue.

Courty. P. E., Smith, P., Koegel, S., Redecker, D., and Wipf, D. 2014. Inorganic Nitrogen uptake and transport in beneficial plant root-microbe interactions. Critical Reviews in Plant Sciences, this issue.

Duc, G., Agrama, H., Bao, S., Berger, J., Bourion, V., De Ron A. M., Gowda, C. L. L., Mikic, A., Millot, D., Singh, K., Tullu, A., Vandenberg, A., Vaz Patto, M. C., Warkentin, T., and Zong X. 2014. Breeding annual grain legumes for sustainable agriculture: new methods to approach more complex traits and target new cultivar ideotypes. Critical Reviews in Plant Sciences, this issue.

FAOSTAT 2013. www.faostat.fao.org (visited 15 December 2013)

Peix, A., Ramírez-Bahena, M. H., Velázquez, E., Bedmar, E. J. 2014. Bacterial associations with legumes. Critical Reviews in Plant Sciences, this issue.

Phelan, P., Moloney, A. P., McGeough, E. J., Humphreys, J., Bertilsson, J., O’Riordana, E., and O'Kielya, P. 2014. Forage legumes for grazing and conserving in ruminant production systems. Critical Reviews in Plant Sciences, this issue.

Rubiales, D., Fondevilla, S., Chen, W., Gentzbittel, L., Higgins, T. J. V., Castillejo, M. A., Singh, K. B., and Rispail, N. 2014. Achievements and challenges in legume breeding for pest and disease resistance. Critical Reviews in Plant Sciences, this issue.

Smýkal, P., Coyne, C. J., Ambrose, M. J., Maxted, N., Schaefer, H., Blair, M. W., Berger, J., Greene, S. L., Nelson, M. N., Besharat, N., Vymyslický, T., Toker, C., Saxena, R. K., Roorkiwal, M., Pandey, M. K., Hu, J., Li, H. L.,Wang, L. X., Guo, Y., Qiu, L. J., Redden, R. J., and Varshney, R. K. 2014. Legume crops 
phylogeny and genetic diversity for science and breeding. Critical Reviews in Plant Sciences, this issue.

Vaz Patto, M. C., Amarowicz, R., Aryee, A. N., A., Boye, J. I., Chung, H. J., MartínCabrejas, M. A., Domoney, C., 2014. Achievements and challenges in improving the nutritional quality of food legumes. Critical Reviews in Plant Sciences, this issue.

Varshney, R. K., Kudapa, H., Pazhamala, L., Chitikineni, A., Thudi, M., Bohra, A., Gaur, P. M., Janila, P., Fikre, A., Kimurto, P., and Ellis, N. 2014. Translational genomics in agriculture: some examples in grain legumes. Critical Reviews in Plant Sciences, this issue. 
Table 1. Trend for word acreage (Million hectares) per major legume crops in past 50 years compared to major cereal crops (source FAOSTAT, 2013)

\begin{tabular}{|c|c|c|c|c|c|c|}
\hline & 1962 & 1972 & 1982 & 1992 & 2002 & 2012 \\
\hline \multicolumn{7}{|l|}{ Cool-season legumes } \\
\hline Chickpea (Cicer arietinum) & 12,2 & 10,5 & 10,3 & 9,3 & 10,4 & 12,1 \\
\hline Pea (Pisum sativum) & 10,3 & 8,0 & 7,4 & 7,2 & 6,0 & 6,3 \\
\hline Faba bean (Vicia faba) & 6,1 & 4,2 & 3,3 & 2,9 & 2,7 & 2,4 \\
\hline Lentil (Lens culinaris) & 1,6 & 1,8 & 2,6 & 3,3 & 3,6 & 4,2 \\
\hline Vetches (Vicia sp.) & 2,4 & 1,7 & 1,0 & 1,0 & 0,9 & 0,6 \\
\hline Lupins (Lupinus sp.) & 1,4 & 0,8 & 0,6 & 1,2 & 1,2 & 0,9 \\
\hline \multicolumn{7}{|l|}{ Warm-season legumes } \\
\hline Soybean (Glycine max) & 23,8 & 31,7 & 52,4 & 56,2 & 79,0 & 106,6 \\
\hline Common bean (Phaseolus vulgaris) & 23,5 & 22,8 & 26,2 & 24,8 & 27,5 & 28,8 \\
\hline Peanut (Arachis hypogea) & 17,5 & 20,1 & 18,4 & 20,6 & 23,0 & 24,6 \\
\hline Cowpea (Vigna unguiculata) & 2,7 & 4,2 & 3,9 & 8,5 & 9,9 & 10,7 \\
\hline Pigeonpea (Cajanus cajan) & 2,7 & 2,7 & 3,4 & 4,2 & 4,4 & 5,3 \\
\hline \multicolumn{7}{|l|}{ Major cereals, for comparison } \\
\hline Wheat (Triticum aestivum) & 207,6 & 213,8 & 238,5 & 222,5 & 213,8 & 216,7 \\
\hline Rice (Oryza sativa) & 119,5 & 132,2 & 141,6 & 147,4 & 147,6 & 163,5 \\
\hline Maize (Zea mays) & 103,5 & 114,9 & 124,4 & 136,8 & 137,6 & 177,0 \\
\hline
\end{tabular}

